\title{
Growth Performance, Undergrowth Diversity and Carbon Sequestration Potentials of Tree Species Stand Combinations, Ghana
}

\author{
Samuel Novor, Simon Abugre \\ Department of Forest Science, University of Energy and Natural Resources, Sunyani, Ghana \\ Email: simon.abugre@uenr.edu.gh
}

How to cite this paper: Novor, S., \& Abugre, S. (2020). Growth Performance, Undergrowth Diversity and Carbon Sequestration Potentials of Tree Species Stand Combinations, Ghana. Open Journal of Forestry, 10, 135-154.

https://doi.org/10.4236/ojf.2020.101010

Received: February 27, 2019

Accepted: January 7, 2020

Published: January 10, 2020

Copyright $\odot 2020$ by author(s) and Scientific Research Publishing Inc. This work is licensed under the Creative Commons Attribution International License (CC BY 4.0).

http://creativecommons.org/licenses/by/4.0/

\section{c) (i) Open Access}

\begin{abstract}
The limited number of studies on mixed plantations makes it difficult to accurately predict success of mixed-species combination especially with regards to growth, undergrowth diversity and carbon sequestration potentials. This study therefore provides information on the effects of Ceiba pentandra, Terminalia superba, Cedrela odorata and Khaya anthotheca in three different stand combinations on growth, undergrowth diversity and carbon sequestration potential. A 15-year-old coupe of 32 ha of mixed tree species stand combinations was selected for the study. The coupe was stratified based on the species combinations. Nested sub-plots $(25 \mathrm{~m} \times 25 \mathrm{~m})$ were randomly laid in different species stand combinations for growth data collection. In each nested sub-plot, $1 \mathrm{~m} \times 1 \mathrm{~m}$ plots were also randomly laid for undergrowth diversity study. The results revealed that two species stand combination of Ceiba pentandra and Terminalia superba performed better in terms of growth, carbon sequestration and carbon content as compared to the other species stand combinations. The saplings on the other hand, were more diverse under the three species stand combination plots. Also, the effective number of species, species richness, evenness, and dominance were higher in the four species stand combination plots. Generally, Ceiba pentandra and Terminalia superba are compatible as it produced the highest growth and carbon sequestration potential.
\end{abstract}

\section{Keywords}

Species Combination, Growth, Floristic Composition, Carbon Content, Saplings

\section{Introduction}

Forests play an important role in the advancement of a nation. Aside from their 
contribution to national GDP, they assume an extremely key role in the livelihood of the populace who depend directly or indirectly on it for their survival (Angelsen et al., 2014). Forests are the most fundamental natural and financial assets that help the prosperity of human social needs. Food, nutrition, income, energy and shelter are the benefits rural people in developing countries derived directly and indirectly from forests (Jamnadass et al., 2011).

Forests also provide non-timber forest products (NTFPs) which make up $0.6 \%$ of all nourishment globally (FAO, 2014). Forest provides fuelwood as the main energy option for 2.4 billion individuals for cooking and 750 million individuals who boil water to diminish the dangers of water-borne diseases (FAO, 2014). The forest sector formally employs approximately 13.2 million individuals whereas 41 million people are informally engaged in the sector and create basic earnings to enable access to food (World Bank, 2016).

Despite its importance, forest cover has been declining over the years (FAO, 2015). Studies have established that the most ideal approach to recover lost forest is through the establishment of plantations either as pure or mixed stands. However, there have been debates among researchers on the best combinations of tree species and their impact on saplings and undergrowth diversity. Likewise, undergrowth diversity of plantations has been a subject of much discussion particularly for quick growing plantations (Tang et al., 2007). A study by Montagnini et al. (1995) revealed that mixed-species plantations create more biomass per unit zone since competition among individuals is lessened and the site is utilized optimally.

Parrotta \& Knowles (1999) additionally expressed that for indigenous species, mixed plantation appears to be the most appropriate for providing a more extensive scope of choices, for example, production, protection, biodiversity protection, and restoration of degraded areas (Piotto, 2008). Likewise, various studies have recorded an extensive variety of native forest plants and animals in mixed plantation (Barbaro et al., 2005; Carnus et al., 2006). According to Carnevale \& Montagnini (2002), the biodiversity of the mixed plantation is more prominent than that of the pure plantation.

The drive for the establishment of a mixed plantation can be ascribed to its marketing opportunities, biodiversity protection or tolerant to diseases and pest (Vanclay, 2006).

Forrester et al. (2006) stated that there is a lack of adequate information on mixed plantations which makes precise prediction of their growth dynamics, undergrowth diversity and their carbon sequestration potentials very difficult. Also, limited studies exist on species combination of native plant species in mixed plantations and their impacts on undergrowth diversity as well as their carbon sequestration potentials. Mixed plantations findings have been reported without regard to the species combinations. Some species could have allelopathic properties which could be detrimental in mixed plantations. Therefore, it is necessary to contribute to the debate by examining the growth performance of different species stand combinations of Ceiba pentandra (Ceiba) and Terminalia 
superba (Ofram), Ceiba pentandra (Ceiba), Terminalia superba (Ofram) and Cedrela odorata (Cedrela), Ceiba pentandra (Ceiba), Terminalia superba (Ofram), Khaya anthotheca (Mahogany) and Cedrella odorata (Cedrella) in different mixed forest stands at the Ayum Forest Project Limited's plantation in Amama Forest Reserve of the Sunyani Forest District. These species are the most commonly used in mixed plantations in Ghana. Information on how these species perform in mixed planation is vital for the industry.

\section{Materials and Methods}

\section{Description of the study area}

The study was carried out in the Amama Forest Reserve in the Sunyani Forest District, Brong Ahafo Region. The area is located about $12 \mathrm{~km}$ southwest of Sunyani and approximately between latitude $7^{\circ} 00^{\prime} \mathrm{N}$ and $7^{\circ} 15^{\prime} \mathrm{N}$ and longitude $2^{\circ} 05^{\prime} \mathrm{W}$ and $2^{\circ} 30^{\prime} \mathrm{W}$. It covers an area of $44 \mathrm{~km}^{2}$ (Figure 1). Ecologically, the reserve forms part of the north-western block of the moist semi-deciduous forest zone of Ghana (Hall \& Swaine, 1981; Hawthorne \& Abu-Juam, 1993).

\section{Experimental plot layout}

The study was conducted in a 32 ha (coupe 2003) with different species combination of Ceiba pentandra and Terminalia superba (Treatment 1), Ceiba pentandra, Terminalia superba and Cedrella odorata, (Treatment 2), Ceiba pentandra, Terminalia superba, Khaya anthotheca and Cedrella odorata (Treatment 3) in the Ayum Forest Project Limited's plantation in Amama Forest Reserve of the Sunyani Forest District. The coupe was stratified based on the species combinations.

Each stratum was further divided into nested sub plots of $25 \mathrm{~m} \times 25 \mathrm{~m}$ plots, from which three plots were randomly selected for growth assessment. In each nested sub plot of $25 \mathrm{~m} \times 25 \mathrm{~m}$ plot, a $1 \mathrm{~m} \times 1 \mathrm{~m}$ square quadrat was laid

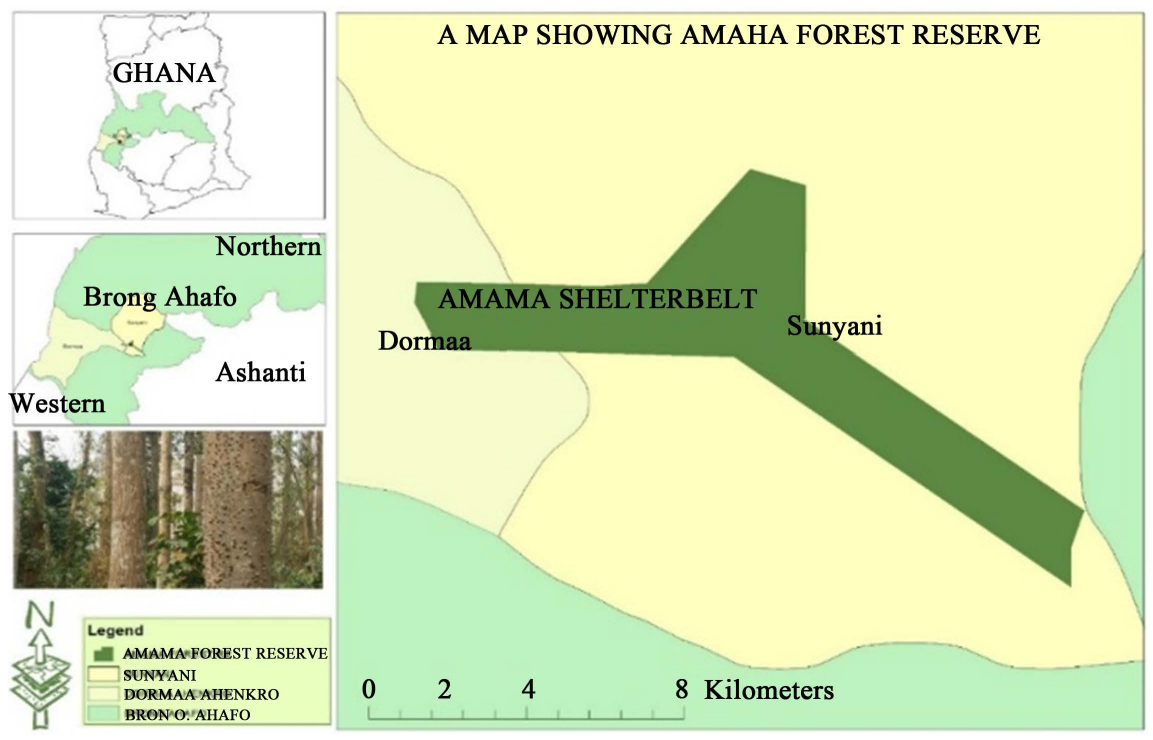

Figure 1. Location of the Amama Forest Reserve, study area. 
randomly for undergrowth diversity assessment. This procedure was repeated for the various tree species combinations (Figure 2).

\section{Data collection}

In each $25 \mathrm{~m} \times 25 \mathrm{~m}$ plot, all the trees species $>10 \mathrm{~cm}$ diameter were measured and enumerated. Data was collected on diameter at breast height $(d b h)$, and total height. In each $1 \mathrm{~m} \times 1 \mathrm{~m}$ quadrat undergrowth identification and enumeration for diversity assessment was done. All saplings within each plot were also measured and enumerated.

Growth performance of the different species stand combinations

Height $(\mathrm{m})$ of each tree (above ground level) was measured using measuring rod. Other parameters such as volume, survival percentage, stand density, mean annual increments and the basal area were estimated using the following formulae:

$$
\text { Tree Volume }=a \times B d b h \times H
$$

where,

$a$ is the stem form factor.

$B d b h$ is the diameter at breast height.

$H$ is the total height.

The value of " $a$ " was set to 0.5 (Ugalde, 2000).

Stand density, survival rate and the basal area were estimated as reported by Nkyi (2007)

The basal area $\left(\mathrm{m}^{2} / \mathrm{ha}\right)=0.00007854 \times d b h^{2}$.

0.00007854 is a constant,

$$
\begin{gathered}
\text { Stand Density }=\frac{\text { Number of trees in a plot }}{\text { The area of Plot }} \times 10000 \mathrm{~m}^{2} \\
\text { Survial } \%=\frac{\text { Number of trees survived }}{\text { Total number of trees planted }} \times 100 .
\end{gathered}
$$
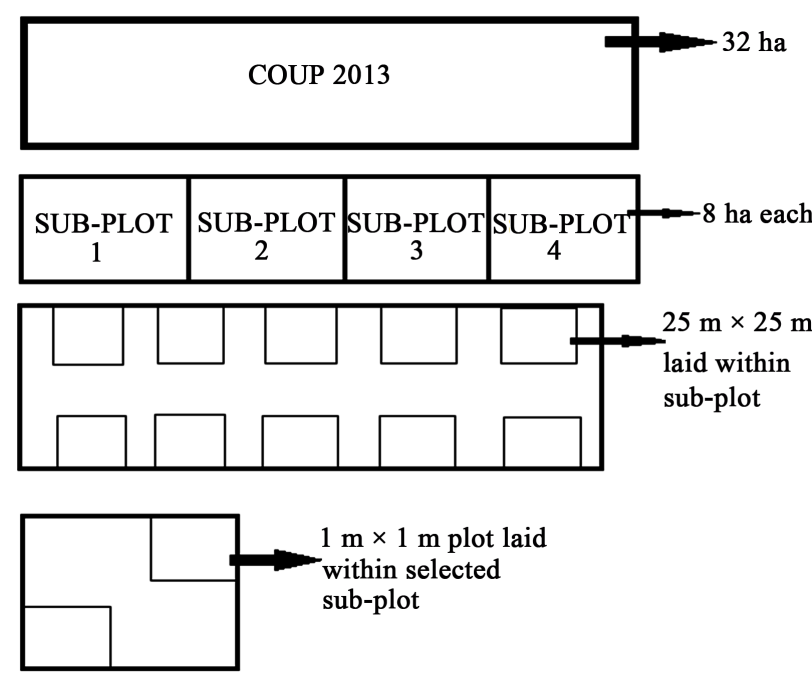

Figure 2. Design for the selection of coupe, sample and sub plots. 
Understory floristic composition and diversity of the mixed species stand combinations.

Within the $25 \mathrm{~m} \times 25 \mathrm{~m}$ plot, trees $<10 \mathrm{~cm}$ diameter (saplings) were enumerated and species composition assessed to determine the sapling diversity in each of the plots. The saplings and undergrowth plant species collected were sent to the Forest Research Institute of Ghana (FORIG) for identification. Also, the field guide (classification catalogue) was used to identify plant species in-situ. The diameter of all identified trees was measured over-bark at breast height $(1.3 \mathrm{~m})$ with a girth tape and height $(\mathrm{m})$ measured with a measuring rod.

The Shannon Wiener's diversity index $(H)$ was used as a measure of diversity. This index takes both species abundance and species richness into consideration (Heusèrr, 1998) and is the most commonly used index (Kent \& Coker, 1996). The Shannon Wiener's diversity index $(H)$ was calculated using the formula:

$$
H^{\prime}=-\Sigma(p i \ln p i)
$$

where, $p i$ is the proportion of individuals found in species $i$. For a well-sampled community, we can estimate this proportion as $p i=n i / N$, where $n i$ is the number of individuals in species $i$ and $N$ is the total number of individuals in the community.

The Simpson's index of dominance was measured and calculated using the formula:

$$
D=\frac{\sum n(n-1)}{N(N-1)}
$$

where; $n=$ the total number of organisms of a particular species, $N=$ the total number of organisms of all species.

Simpson's Index of Diversity $=1-D$.

The coefficient of similarity of Sorensen $(K)$ was determined by the formula:

$$
K=\frac{2 c}{a+b} \times 100
$$

where, $a=$ number of species of the statement $1, b=$ number of species of the statement 2, $c=$ number of species common to the two statements (Ngueguim et al., 2010).

Carbon sequestration potentials of the various mixed species stand combination

The biomass estimation method was used to calculate the per unit amount of carbon sequestered. The above-ground biomass (AGB) of trees was measured by the regression equation of biomass as a function of diameter at breast height (Brown et al., 1989).

$$
\mathrm{AGB}=\exp \left\{-2.4090+0.9522 \ln \left(D^{2} H S\right)\right\}
$$

where: AGB is the above-ground biomass in average dry matter per hectare.

$H$ is the height of the trees in meters (average height);

$D$ is the diameter at breast height $(1.3 \mathrm{in} \mathrm{cm})$; 
$S$ is the wood density per hectare.

For calculating the below ground biomass (BGB), the allometric equation developed by Kuyah et al. (2012) was used:

$$
\mathrm{BGB}_{\mathrm{est}}=0.048 \times(d b h)^{2.303} \text {. }
$$

The carbon content of each tree in the plots was calculated by multiplying the modelled dry weight biomass by 0.5 (IPCC, 2006).

Biomass carbon content $=$ Biomass weight $(\mathrm{tdm} / \mathrm{ha}) * 0.5 \mathrm{tC} / \mathrm{tdm}$

where: $\mathrm{tC}$ stands for tons of carbon and tdm for tons of dry matter.

The carbon dioxide equivalent $\left(\mathrm{CO}_{2}\right)$ was estimated by multiplying the carbon stock by 3.67 (Kauffman \& Donato, 2012).

The monetary value of carbon sequestered by the various stand combinations is calculated as:

1 tonne of carbon $=\$ 10$ (USD).

\section{Data analysis}

The one-way Analysis of Variance (ANOVA) was performed to test the differences in the growth parameters between the various species combinations.

The diversity of understory species in the forest plantation stands were determined using the Shannon-Wiener species diversity index, Simpson index of dominance and the effective number of species (Blanc et al., 2000; Parthasarathy, 2001; Krebs, 2001; Addo-Fordjour et al., 2009).

\section{Results}

\section{Survival percentage of tree species}

The findings of the study indicate a high survival percentage of $81.5 \%$ and $61.7 \%$ for Terminalia superba and Ceiba pentandra respectively in the two species stand combination compared to three species stand combination in which Terminalia superba and Ceiba pentandra survival percentage were $55.6 \%$ and $35.2 \%$. In the four species stand combination the percentage survival for Terminalia superba and Ceiba pentandra were $44.4 \%$ and $51.9 \%$ respectively (Figure 3).

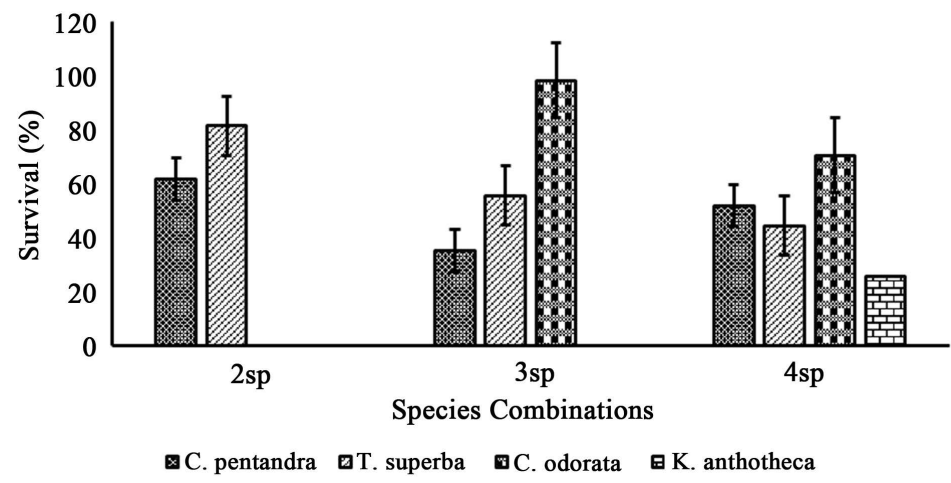

Figure 3. Survival percentage of the individual Species in the various species combinations. 
The lowest survival percentage for Terminalia superba and Ceiba pentandra was recorded in the three species combinations $(p<0.05)$. C. odorata in three species combination of $C$. pentandra, T. superba and $C$. odorata, recorded the highest survival percentage $98.1 \%$ as compared to $70.4 \%$ survival percentage in four species stand combination for C. odorata, $K$. anthotheca, C. pentandra and T. superba (Figure 3).

\section{Stand density of species}

The average stand density for two species combination was highest, whilst four species combination was lowest (Figure 4).

Within the two species combination, T. superba recorded the highest stand density of 352 trees/ha as compared to C. pentandra of 267 trees/ha. Also, in the three species combination C. odorata, T. superba and C. pentandra, the C. odorata had the highest stand density of 283 trees/ha but this reduced to 203. trees/ha in four species combination of $C$. odorata, T. superba, C. pentandra, and $K$. anthotheca (Figure 4).

Generally, stand density was highest in the two species combination and was significantly different from the three and four species combinations.

\section{Volume of tree species}

The highest average volume $\left(242.8 \mathrm{~m}^{3} / \mathrm{ha}\right)$ was obtained from Ceiba pentan$d r a$ in the two species combination. The volume of Ceiba pentandra volume was $208.9 \mathrm{~m}^{3} / \mathrm{ha}$ in the four species combinations and $201.0 \mathrm{~m}^{3} / \mathrm{ha}$ in three species combination (Figure 5).

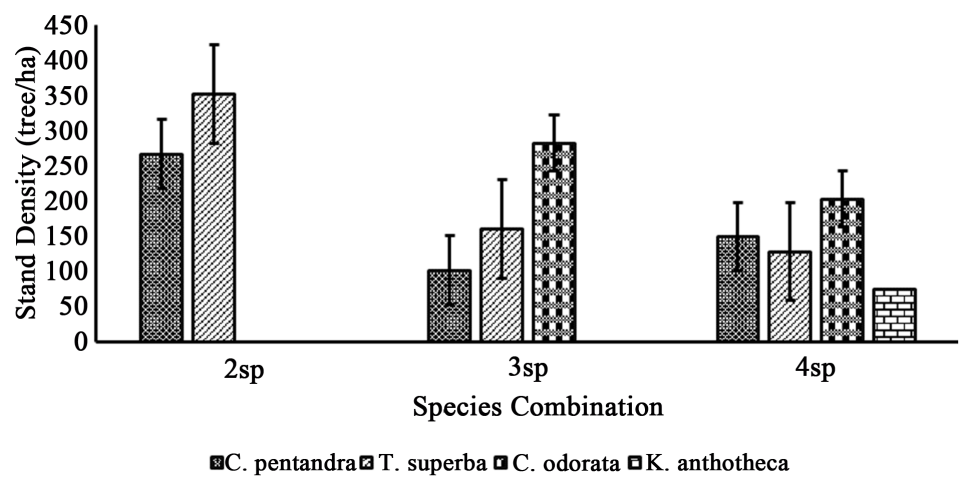

Figure 4. Stand density of the various species stand combinations.

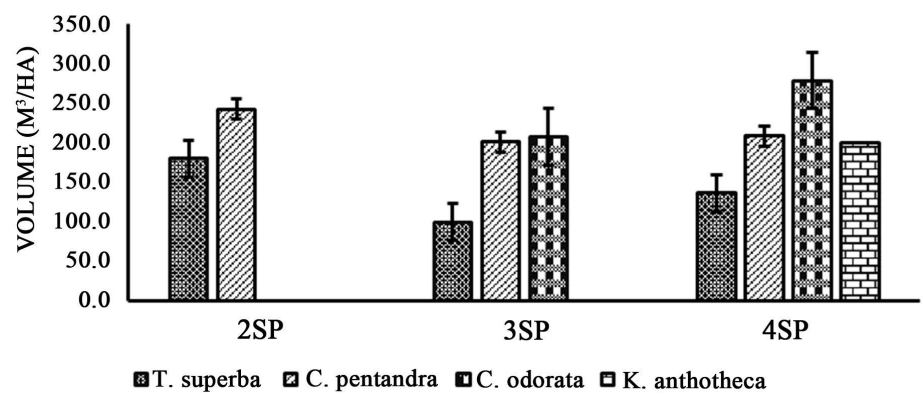

Figure 5. Mean volume of the individual species in the various species stand combinations. 
Similarly, the volume of Terminalia superba volume was highest $\left(180.5 \mathrm{~m}^{3} / \mathrm{ha}\right)$ in the two species combination and was significantly different from Terminalia superba in the three and four species combinations. Further, the results showed that Cedrela odorata in the four species combination had higher average volume of $279.1 \mathrm{~m}^{3} /$ ha which was significantly different from Cedrela odorata in the three species combination $(p<0.05)$ (Figure 5$)$.

\section{Mean Diameter of species}

The mean diameter of Terminalia superba was generally higher in two species combination $25.0 \mathrm{~cm}$ than Terminalia superba in three species combination which was $19.0 \mathrm{~cm}$ and four species combination of $19 \mathrm{~cm}$ (Figure 6).

Generally, the mean diameter of Ceiba pentandra recorded in the two species combination had the highest diameter of $32 \mathrm{~cm}$. The diameter of Ceiba pentan$d r a$ in the three and four species combinations was $29.4 \mathrm{~cm}$ and $29.3 \mathrm{~cm}$ respectively. On the other hand, Cedrela odorata recorded $39.3 \mathrm{~cm}$ in the four species combination against $30.4 \mathrm{~cm}$ in the three species combination but showed no significant difference in their mean diameter $(p<0.05)$ (Figure 6).

\section{Mean Height}

The mean height of Ceiba pentandra in two species combination was $16.0 \mathrm{~m}$ followed by three species combination of $13.6 \mathrm{~m}$ and four species combination of $13.1 \mathrm{~m}$.

The highest mean height of Terminalia superba was $14.5 \mathrm{~m}$ in two species combination compared to $13.8 \mathrm{~m}$ in three species combination and $13.8 \mathrm{~m}$ in four species combination (Figure 7). Cedrela odorata grew better in four species combination with mean height of $14.7 \mathrm{~m}$ compared to $13.6 \mathrm{~m}$ estimated in three species combination (Figure 7).

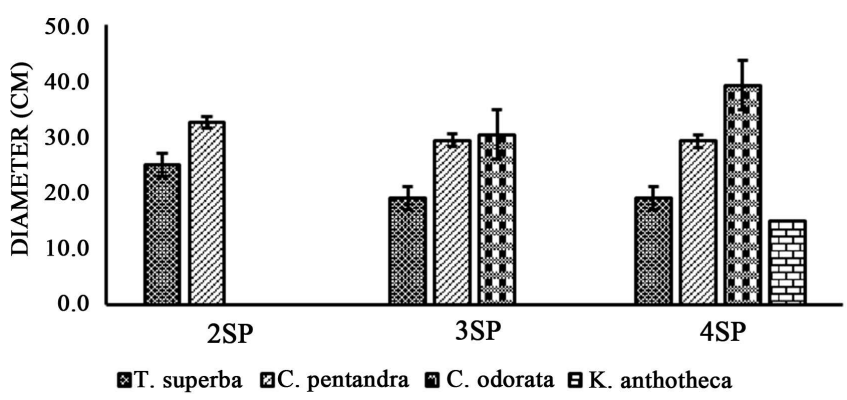

Figure 6. Mean diameter of the individual species of the various species combinations.

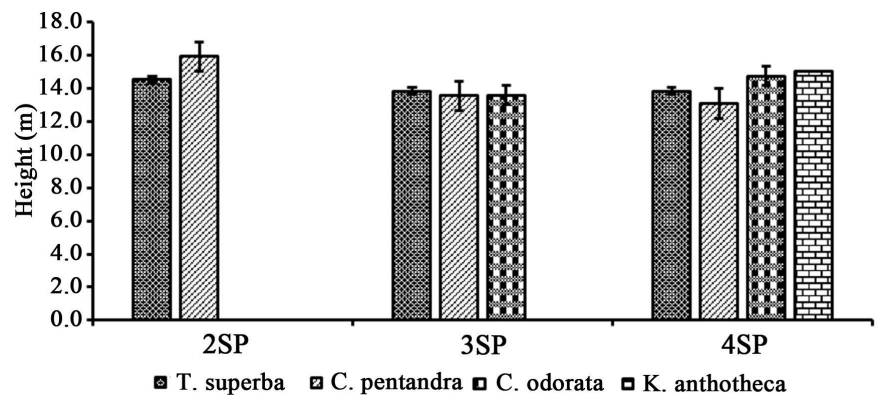

Figure 7. Mean height of the individual species of the various species combinations. 


\section{Saplings Families Diversity}

The total count of saplings by families in the various species combinations were 73,133 and 77 for two, three and four species combinations respectively. Two species combination had saplings belonging to 11 different families, three species combination had saplings belonging to 12 different families and four species combination had 7 families in the identified saplings. Fabaceae was the most abundant family in the various species combinations which were $41.10 \%$, $53.3 \%$ and $50.6 \%$ in two, three and four species combinations respectively. It was followed by Sterculiaceae, Apocynaceae, Bignoniaceae, Combretaceae, Griseliniaceae, Malvaceae, Meliaceae, Pandaceae, Rubiaceae, Sapindaceae, and Urticaceae families (Table 1).

\section{Coefficient of similarity of Sorensen $(\mathrm{K})$}

The results in Figure 8 indicate that two and three species combinations had the highest coefficient of similarity of Sorensen $(K)$ of $48.65 \%$. Three and four species combinations had the least similarity of $45.71 \%$ and $47.06 \%$ respectively.

\section{Shannon Weiner Diversity Index}

In Figure 9, diversity index was high in the four species combination followed by two species combination and least in three species combination.

\section{Effective Number of Species}

The effective number of species in four species combination was highest and lowest in two species combination (Figure 10).

\section{Simpsons Diversity Index}

Table 1. Saplings families diversity under the various species combinations.

\begin{tabular}{|c|c|c|c|}
\hline COUNT OF FAMILY & 2 SPECIES & 3 SPECIES & 4 SPECIES \\
\hline Apocynaceae & 4 & 4 & 14 \\
\hline Bignoniaceae & 0 & 0 & 1 \\
\hline Bombacaceae & 0 & 1 & 0 \\
\hline Combretaceae & 3 & 1 & 0 \\
\hline Euphorbiaceae & 8 & 0 & 0 \\
\hline Fabaceae & 30 & 71 & 39 \\
\hline Griseliniaceae & 11 & 0 & 0 \\
\hline Malvaceae & 0 & 8 & 1 \\
\hline Meliaceae & 9 & 8 & 4 \\
\hline Moraceae & 6 & 8 & 4 \\
\hline Pandaceae & 5 & 1 & 0 \\
\hline Rubiaceae & 0 & 0 & 1 \\
\hline Sapindaceae & 9 & 15 & 3 \\
\hline Sterculiaceae & 2 & 1 & 8 \\
\hline Urticaceae & 0 & 0 & 1 \\
\hline Total & 73 & 133 & 77 \\
\hline
\end{tabular}




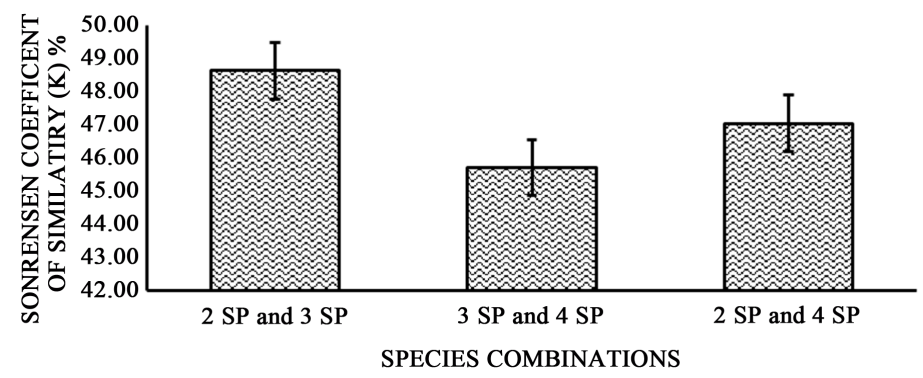

Figure 8. Sorensen coefficient of similarity for the various species.

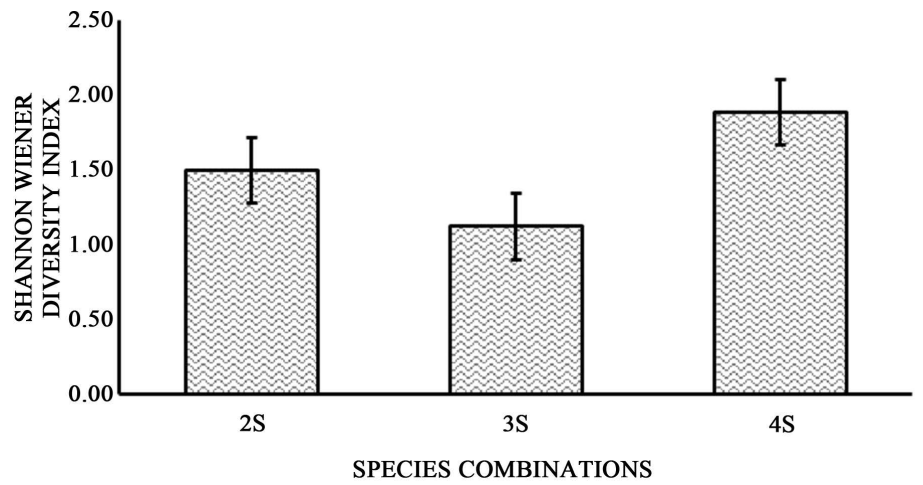

Figure 9. Shannon Weiner diversity index of the various species combinations.

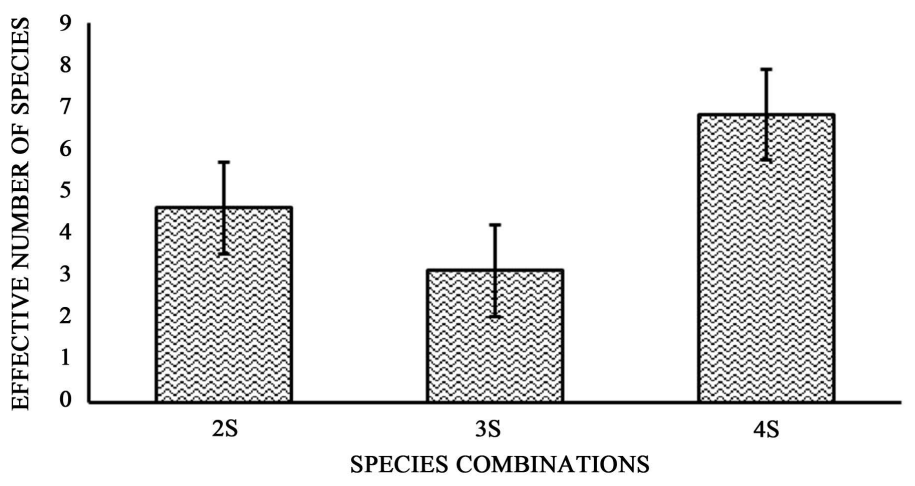

Figure 10. Effective number of species for various species combinations.

Measure of dominance recorded an ascending order from two, three and four species combinations. Four species combination occupied the highest dominance followed by three species combination with two species combination having the least (Figure 11).

\section{Saplings Height and Diameter}

Saplings within two species combination had the highest mean height which was significantly different $(p<0.05)$ from the other species combinations. Three species combination had the least mean height but not significantly different ( $p$ $<0.05)$ from the four species combination. Two species combination had the highest mean diameter followed by three species combination. Two species combination was not significantly different $(p<0.05)$ from three species combination but different $(p<0.05)$ from four species combination (Table 2$)$. 


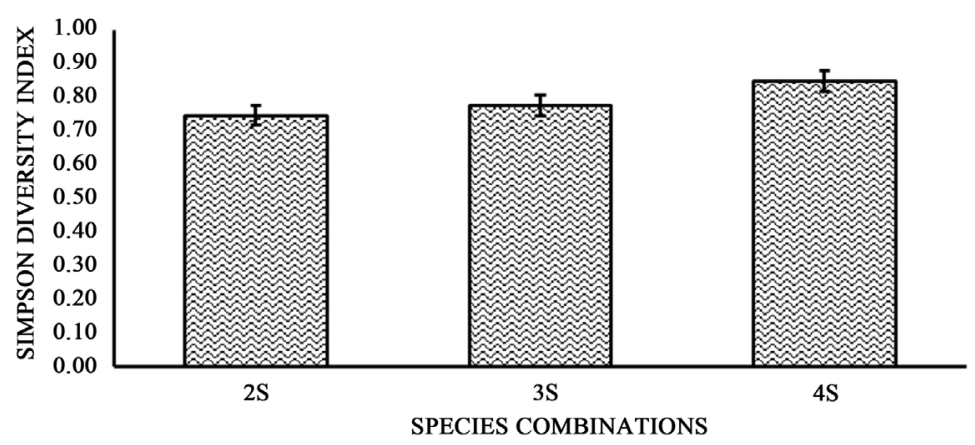

Figure 11. Simpson's diversity for the various species combinations.

Table 2. Species homogeneity for mean height and mean diameter of the species combinations.

\begin{tabular}{ccccc}
\hline Groups & $\begin{array}{c}\text { Mean Height } \\
(\mathrm{m})\end{array}$ & $\begin{array}{c}\text { Homogeneous } \\
\text { Groups }\end{array}$ & $\begin{array}{c}\text { Mean Diameter } \\
(\mathrm{cm})\end{array}$ & $\begin{array}{c}\text { Homogeneous } \\
\text { Groups }\end{array}$ \\
\hline 2 SPECIES & 5.1418 & $\mathrm{~A}$ & 6.2386 & $\mathrm{~A}$ \\
3 SPECIES & 3.2492 & $\mathrm{~B}$ & 5.1153 & $\mathrm{AB}$ \\
4 SPECIES & 3.4929 & $\mathrm{~B}$ & 3.9145 & $\mathrm{~B}$ \\
\hline
\end{tabular}

Means along the column with the same letter are not significantly different $(p<0.05)$.

Estimation of Above Ground Biomass (AGB), Below Ground Biomass (BGB), Total Carbon Storage (TCS), Biomass Carbon Content (BCC), Carbon Dioxide $\left(\mathrm{CO}_{2}\right)$ and Monetary Values of the various Species combinations

Within two species combination, Terminalia superba recorded the highest aboveground biomass of $306.7 \mathrm{t} / \mathrm{ha}$ as against $216.1 \mathrm{t} / \mathrm{ha}$ for Ceiba pentandra. Ceiba pentandra recorded the highest belowground biomass (BGB) estimate of $169.1 \mathrm{t} / \mathrm{ha}$ within two species combination. It was also higher when compared to three and four species combinations (Table 3 ).

Cedrela odorata also recorded the highest above and below ground biomass of $465.2 \mathrm{t} / \mathrm{ha}$ and $259.0 \mathrm{t} / \mathrm{ha}$ respectively in four species and three species combination.

Again, Terminalia superba in the two species combination had the highest total carbon storage (TCS), biomass carbon content (BCC), carbon dioxide $\left(\mathrm{CO}_{2}\right)$ and monetary value compared to Ceiba pentandra within the two species combination. It also recorded the highest compared to three and four species combinations.

Cedrella odorata (Cedrella) within four species combination performed well compared to other species in terms of total carbon storage (TCS), biomass carbon content (BCC), carbon dioxide $\left(\mathrm{CO}_{2}\right)$ and monetary value (Table 3).

Estimation of Total above Ground Biomass (AGB), Below Ground Biomass (BGB), Total Carbon Storage (TCS), Biomass Carbon Content (BCC), Carbon Dioxide $\left(\mathrm{CO}_{2}\right)$ and Monetary Values of the various Species combinations 
Generally, the total aboveground biomass of $9846.69 \mathrm{t} / \mathrm{ha}$, total belowground biomass of $5595.48 \mathrm{t} /$ ha, total carbon storage of $15,442.17 \mathrm{t} / \mathrm{ha}$, total $\mathrm{CO}_{2}$ stock of $28,310.65 \mathrm{t} / \mathrm{ha}$, and monetary value of $\$ 214,457.8 \mathrm{t} /$ ha was highest in four species combination followed by two and three species combinations respectively (Table $4)$. However, the two, three and four species combination were not significantly different $(p<0.05)$.

Table 3. Above Ground Biomass (AGB), Below Ground Biomass (BGB), Total Carbon Storage (TCS), Biomass Carbon Content (BCC), Carbon Dioxide $\left(\mathrm{CO}_{2}\right)$ and monetary values of the various species combinations.

\begin{tabular}{|c|c|c|c|c|c|c|c|c|c|}
\hline & \multicolumn{2}{|c|}{2 Species } & \multicolumn{3}{|c|}{3 Species } & \multicolumn{4}{|c|}{4 Species } \\
\hline & C. pentandra & T. superba & C. pentandra & T. superba & C. odorata & C. pentandra & T. superba & C. odorata & K. anthotheca \\
\hline AGB (t/ha) & 216.1 & 306.7 & 68.6 & 55.3 & 313.7 & 105.7 & 75.2 & 465.2 & 32.4 \\
\hline BGB (t/ha) & 169.1 & 111.3 & 55.5 & 19.5 & 153.8 & 85.1 & 25.8 & 259.0 & 7.9 \\
\hline TCS (t/ha) & 385.3 & 418.0 & 124. & 74.8 & 467.6 & 190.8 & 101.0 & 724.2 & 40.3 \\
\hline $\mathrm{BCC}(\mathrm{t} / \mathrm{ha})$ & 192.6 & 209.0 & 62.0 & 37.4 & 233.8 & 95.4 & 50.5 & 362.1 & 20.2 \\
\hline $\mathrm{CO}_{2}(\mathrm{t} / \mathrm{ha})$ & 706.3 & 766.4 & 227. & 137.2 & 857.2 & 349.9 & 185.2 & 1327.7 & 73.9 \\
\hline Monetary value (\$) & 7060 & 7660 & 2270 & 1370 & 8570 & 3490 & 1850 & 13270 & 730 \\
\hline
\end{tabular}

Table 4. Total above ground biomass, total below-ground biomass, total carbon stock, total $\mathrm{CO}_{2}$ stock and monetary value of the various species combinations.

\begin{tabular}{ccccccc}
\hline Groups & $\begin{array}{c}\text { Above Ground } \\
\text { Biomass (t/ha) }\end{array}$ & $\begin{array}{c}\text { Below Ground } \\
\text { biomass (t/ha) }\end{array}$ & $\begin{array}{c}\text { Total carbon } \\
\text { Stock (t/ha) }\end{array}$ & $\begin{array}{c}\text { Total } \mathrm{CO}_{2} \\
\text { Stock }(\mathrm{t} / \mathrm{ha})\end{array}$ & $\begin{array}{c}\text { Homogeneous } \\
\text { Groups }\end{array}$ & $\begin{array}{c}\text { Amount } \\
(\$)\end{array}$ \\
\hline 2SPECIES & 8909.78 & 4750.95 & $13,660.73$ & $25,044.67$ & $\mathrm{~A}$ & $2,504,467$ \\
3SPECIES & 7293.46 & 3814.267 & $11,107.73$ & $20,364.17$ & $\mathrm{~A}$ & $2,036,417$ \\
4SPECIES & 9846.69 & 5595.481 & $15,442.17$ & $28,310.65$ & $\mathrm{~A}$ & $2,831,065$ \\
\hline
\end{tabular}

Means along the column with the same letter are not significantly different $(p<0.05)$.

\section{Discussion}

Growth performance and productivity of the various species combinations

The differences in growth parameters of the tree species in plantation such as height, diameter, basal area and volume could be ascribed to species morphological and physiological differences, genetic adaptations as well as the physical environment (Oliver and Larson, 1990). Tree species make use of available space, soil resources and environmental factors to grow. Therefore, mixed plantations with large gaps or spaces create less competition between species. The performance of Ceiba pentandra and Terminalia superba points to their compatibility. Their morphological and genetic adaptation are good in mixed plantation.

Generally, growth performance with respect to average diameter, average height, average basal area, average volume, for Terminalia superba in two species combination was higher compared to other species combinations. This is because Terminalia superba is a fast-growing species compared to Khaya antho- 
theca and Cedrela odorata which are pioneer species (Hawthorne \& Abu-Juam, 1993; Orwa et al., 2009). Consequently, competitions amongst them in mixed stands for growth resources have the potential to lessen the growth of the other species (Petit \& Montagnini, 2006). The result of this study shows a declining trend in productivity of Terminalia superba as the species combination increases. Thus, the greater the inter-specific competition between the T. superba and other species in mixed combinations, the lesser their productivity (Forrester et al., 2004).

Also, the Ceiba pendandra recorded the highest in all the growth parameters. This is because less inter-specific competition between Ceiba pendandra and Terminalia superba. Ceiba pendandra growth reduced as the component trees increases in the various species combinations.

Tree species competition for growth resources (both soil and environmental resources) in mixed plantations is a key factor that determines the growth and productivity of species. Many of these factors accounted for differences observed in the study in relation to their stand density, survival rate, height, diameter and volume. The interrelation of trees species in which one species exerts a negative effect on growth or mortality of the other explains competition (Furuta \& Aloo, 2009; Boyden et al., 2008).

Khaya anthotheca is a light-demanding species which need good amount of sunlight radiations to grow well, therefore the inter-specific competition between Khaya anthotheca and other species for particularly light and other growth resources may have reduced its growth performance accounting for its poor performance in the four species combination (Potvin \& Dutielleul, 2009; Petit \& Montagnini, 2006).

Likewise, increase structure and biological resemblances of Khaya anthotheca and other tree species could intensify competition between these species which caused a reduction in growth and productivity of $K$. anthotheca in the mixed plantation (Boyden et al., 2008). Opoku (2012) affirms that Khaya anthotheca might not do well when it is planted in combinations with fast growing species. Its interaction with Ceiba pentandra, a fast-growing species was detrimental to its growth.

According to Oliver \& Larson (1996), when species lack competitive vigour they slow their growth performance. Orwa et al. (2009) indicated that Cedrela odorata has the ability to displace indigenous plants by blocking out sunlight with its leaves. The gaps created by the Khaya anthotheca as a result of poor survival percentage and stand density generated less competition between the species. The study agrees with Lamprecht (1989) who observed that tree species make use of available space, soil resources and environmental factors to grow. Nketia (2002), emphasized that the correct spacing of trees in plantations affects the total output in growth parameters such as tree diameter, tree height, basal area and volume.

One of the major traits of Khaya spp. in the mixed plantation is the attack by Hypsipyla robusta, shoot borers, that kill the main stem of young trees and cause extreme branching which contributes to mortality (Opuni-Frimpong, 2008). 
Therefore, the incident of Hypsipyla robusta, may have accounted for the low survival percentage recorded by Khaya anthotheca.

According to Orwa et al. (2009), fast-growing species like Cedrela odorata faces less competition in mixed plantations and therefore utilized the available environmental factors and resources to grow. Less competition for resources in the four species combination as results of low survival percentages of Khaya anthotheca might have led to the good performance of Cedrela odorata. For better productivity and improvement in growth of mixed species, the required resources for growth should be supplied whiles decreasing competition among species (Piotto, 2008; Forrester et al., 2006).

\section{Floristic Composition and Diversity Assessment}

Forest floristic diversity and structure composition is an instrument for sustainability of forests because they contribute to the conservation of plant species and the treatment of forest ecosystems as a whole (Tilman, 1988; Ssegawa \& Nkuutu, 2006).

Fabaceae was the most abundant family in the plots making up $41.10 \%$, $53.38 \%$ and $50.65 \%$ in two, three and four species combinations. This is because Baphia nitida species was the most abundant in all the plots. This may signify their broader variety of ecological adaptation. Results by Senbeta et al. (2005); Addo-Fordjour et al. (2008), follow the same trend where ten tree species, three lianas and two shrubs were identified in all the three forest blocks.

Apocynaceae, Bignoniaceae, Combretaceae, Griseliniaceae, Malvaceae, Meliaceae, Pandaceae, Rubiaceae, Sapindaceae, Sterculiaceae and Urticaceae were the other families identified in the study area. Asase \& Oteng-Yeboah (2007) and Asase et al. (2009) stated that Leguminosae and Combretaceae families were the main understory tree families. Lawson (1986) opines that most of these families are among those identified as common in the forest vegetation of West Africa.

The study revealed that leguminous trees such as Baphia nitida, Pterocarpus erinaceus, Baphia pubescens, and Albizia adianthifolia were high in the study area. The presence of these species in the various species combinations may show their broader range of ecological adaptation (Senbeta et al., 2005; Addo-Fordjour et al., 2008).

The coefficient of similarity of Sorensen $(\mathrm{K})$ was used to quantify the range of similarity in floristic composition amongst the plots. The similarity of understory species composition between two and three species combinations was $48.65 \%$. This shows that about $51.35 \%$ of species between the two plots are different. Three and four species combinations had the Sorenson's coefficient of similarity index value of $45.71 \%$, which showed that $54.29 \%$ of species between the two plots are different whiles two and four species combinations had $47.06 \%$ percent of the saplings available in both combinations. Krebs (2001) stated that, when the similarity index value between two combination treatments is below 0.5 , the two areas are measured as dissimilar in terms of species composition. This study's findings are consistent with that of Akoto et al. (2015) who found species 
composition amongst Cedrela odorata and natural forest to be dissimilar.

The variation in the species composition between the various species combinations could be attributed to changes in environmental conditions and species composition of the various plots. The intensity of sunlight that touched the plantation floor to induce maximum regeneration could have been influenced by canopy closure. The microsites vary as a function of gap size, shape and orientation in relation to the height of neighbouring trees (Canham et al., 1990). The creation of gaps by the mortality of $K$. anthotheca could have affected the diversity in the species combination.

Otsamo (2000) affirmed that when plantation canopy closes, the physical considerations for forest tree seeds germination are controlled and aggressive grasses are shaded out.

\section{Carbon sequestration potentials of the various treatments}

Carbon sequestration of Ceiba pentandra and Terminalia superba were high in two species combination, followed by four species combination. Similarly, Ceiba pentandra, Milicia excelsa, Terminalia superba and Terminalia ivorensis recorded the highest carbon sequestration per tree in a study (Stanley \& Montagnini, 1999; Shepherd \& Montagnini, 2001). This phenomenon could be influenced by species wood density and growth pattern (Redondo-Brenes, 2007). On the other hand, Khaya anthotheca attained the least carbon as a result of low stand density in four species combination. The outcome of this study supports Redondo-Brenes \& Montagnini (2006) findings that quick-growing tree species accumulates high above ground biomass and carbon content.

Cedrela odorata is an exotic and fast-growing species. Carbon sequestration largely depends on the height and tree diameter at breast height. Therefore, the higher the height and diameter, the better the sequestration potential. The study revealed that the highest aboveground biomass for Cedrela odorata in three and four species combinations were $313.73 \mathrm{t} / \mathrm{ha}$ and $465.21 \mathrm{t} / \mathrm{ha}$ respectively. Since aboveground biomass was higher in Cedrela odorata than other tree species in three and four species combinations, it may infer that photosynthesis could have been higher in Cedrela odorata than the other tree species. Although aboveground respiration was not measured, it could be a huge constituent of complete principal production (Ryan, 1991).

Furthermore, the study showed that the growth performance in terms of survival percentage, trees density, average basal area, average volume, average diameter and the average height of Cedrela odorata was higher in two species than three and four species combinations. This affected both above and below ground biomass, overall carbon stock, total $\mathrm{CO}_{2}$ stock and the monetary value of the Cedrela odorata, Terminalia superba and Khaya anthotheca species. It reported that the phenology of roots or shoots growth may differ, therefore competition for soil resources will be less compared to the pure stand plantations. This means that the competition for soil resources between Cedrela odorata, and other tree species in plantation will be greater. 
Values of carbon per hectare for plantations were lower $\left(0.0250 \mathrm{Mg} \cdot \mathrm{ha}^{-1}\right.$, $0.0203 \mathrm{Mg} \cdot \mathrm{ha}^{-1}, 0.0283 \mathrm{Mg} \cdot \mathrm{ha}^{-1}$ ) for two, three and four species combinations respectively compared to values obtained by Montagnini \& Nair (2004) in the study which focused on the overall above ground carbon content of ten plantation-tree species at La Selva, Costa Rica (i.e. 17.3 to $82 \mathrm{Mg} \cdot \mathrm{ha}^{-1}$ ). Also, carbon values per hectare recorded from this study were lower than the values stated for tree plantations in the tropical which range between 8 and $78 \mathrm{Mg} \mathrm{C} \mathrm{ha}^{-1}$ (Schroeder, 1992). The planting distance from this study allowed a limited number of trees to be selected which influenced carbon stock.

Growth performance was generally better in the two species combination compared to those in the other combinations. The floristic composition and diversity in three species combination recorded the highest families followed by the two species combination and four species combination. The different species combination was largely dissimilar. The study revealed that carbon sequestration was highest in the four species combination compared to three and two species combinations.

\section{Conclusion}

The integration of two or more species in plantation forestry could be detrimental if the species are not compatible. The choice of tree species which are compatible is vital for plantation forestry. Terminalia superba and Ceiba pentandra thrived well in mixed plantations. They also promoted plant diversity and enhanced carbon sequestration. Generally, the composition of the mixed plantation is important to enhance its productivity.

\section{Acknowledgements}

We are grateful to the management of Ayum Forest Products Limited who allowed us to use their concession which is located in the Amama forest reserve of Ghana for the study.

\section{Conflicts of Interest}

We the authors declare that there is no conflict of interest regarding the publication of this manuscript.

\section{Data Availability Statement}

Data would be made available when requested.

\section{Funding Statement}

This is an MPhil thesis and it was funded from the student's personal funds.

\section{References}

Addo-Fordjour, P., Anning, A. K., Atakora, E. A., \& Agyei, P. S. (2008). Diversity and Distribution of Climbing Plants in a Semi-Deciduous Rain Forest, KNUST Botanic 
Garden, Ghana. International Journal of Botany, 4, 186-195.

https://doi.org/10.3923/ijb.2008.186.195

Addo-Fordjour, P., Obeng, S., Addo, M. G., \& Anning, A. K. (2009). Floristic Composition, Structure and Natural Regeneration in a Moist Semi-Deciduous Forest Following Anthropogenic Disturbances and Invasion. International Journal of Biodiversity and Conservation, 1, 21-37.

Akoto, S. D., Asare, A., \& Gyabaa, G. (2015). Natural Regeneration Diversity and Composition of Native Tree Species under Mono-Culture, Mixed-Culture Plantation and Natural Forest. International Research Journal of Natural Sciences, 3, 24-38.

Angelsen, A., Jagger, P., Babigumira, R., Belcher, B., Hogarth, N. J., Bauch, S., \& Wunder, S. (2014). Environmental Income and Rural Livelihoods: A Global-Comparative Analysis. World Development, 64, 12-28. https://doi.org/10.1016/j.worlddev.2014.03.006

Asase, A., \& Oteng-Yeboah, A. A. (2007). Assessment of Plant Biodiversity in Wechiau Community Hippopotamus Sanctuary in Ghana. Journal of the Botanical Research Institute of Texas, 1, 549-556.

Asase, A., Patrick, K. E., \& John, Y. A. (2009). Floristic Composition, Abundance and Distribution Pattern of Woody Plants in a Tropical Savanna in Northern Ghana. Journal of the Botanical Research Institute of Texas, 3, 309-316.

Barbaro, L., Pontcharraud, L., Vetillard, F., Guyon, D., \& Jactel, H. (2005). Comparative Responses of Bird, Carabid, and Spider Assemblages to Stand and Landscape Diversity in Maritime Pine Plantation Forests. Ecoscience, 12, 110-121.

https://doi.org/10.2980/i1195-6860-12-1-110.1

Blanc, L., Maury-Lechon, G., \& Pascal, J.-P. (2000). Structure, Floristic Composition and Natural Regeneration in the Forests of Cat Tien National Park, Vietnam: An Analysis of the Successional Trends. Journal of Biogeography, 27, 141-157. https://doi.org/10.1046/j.1365-2699.2000.00347.x

Boyden, S., Binkley, D., \& Stape, J. L. (2008). Competition among Eucalyptus Trees Depends on Genetic Variation and Resource Supply. Ecology, 89, 2850-2859. https://doi.org/10.1890/07-1733.1

Brown, S., Gillespie, A. J., \& Lugo, A. (1989). Biomass Estimation Methods for Tropical Forests with Applications to Forest Inventory Data. Forest Science, 35, 881-980.

Canham, C. D., Denslow, J. S., Platt, W. J., Runkle, J. R., Spies, T. A., \& White, P. S. (1990). Light Regimes beneath Closed Canopies and Tree-Fall Gaps in Temperate and Tropical Forests. Canadian Journal of Forest Research, 20, 620-631. https://doi.org/10.1139/x90-084

Carnevale, N., \& Montagnini, F. (2002). Facilitating Regeneration of Secondary Forests with the Use of Mixed and Pure Plantations of Indigenous Tree Species. Forest Ecology and Management, 163, 217-227. https://doi.org/10.1016/S0378-1127(01)00581-3

Carnus, J. M., Parrotta, J., Brockerhoff, E., Arbez, M., Jactel, H., Kremer, A., Lamb, D., O'Hara, K., \& Walters, B. (2006). Facilitating Plantation in the Tropics for Better Afforestation.

FAO (2014). State of World's Forests: Enhancing the Socioeconomic Benefits from Forests. Rome: Food and Agriculture Organization.

FAO (2015). Global Forest Resources Assessment. Rome: FAO Report.

Forrester, D. I., Bauhus, J., \& Khanna, P. K. (2004). Growth Dynamics in a Mixed-Species Plantation of Eucalyptus globulus and Acacia mearnsii. Forest Ecology and Management, 193, 81-95. https://doi.org/10.1016/j.foreco.2004.01.024

Forrester, D. I., Bauhus, J., Cowie, A. L., \& Vanclay, J. K. (2006). Mixed-Species Planta- 
tions of Eucalyptus with Nitrogen-Fixing Trees: A Review. Forest Ecology and Management, 233, 211-230. https://doi.org/10.1016/j.foreco.2006.05.012

Furuta, K., \& Aloo, I. K. (2009). Between-Tree Distance and Spread of the Sakhalin Fir Aphid (Cinara Todocola Inouye) (Hom. Aphididae) within a Plantation. Journal of Applied Entomology, 117, 64-71. https://doi.org/10.1111/j.1439-0418.1994.tb00708.x

Hall, J. B., \& Swaine, M. D. (1981). Distribution and Ecology of Vascular Plants in a Tropical Rain Forest: Forest Vegetation in Ghana (p. 383). The Hague: W Junk Publishers. https://doi.org/10.1007/978-94-009-8650-3

Hawthorne, W. D., \& Abu-Juam, M. (1993). Forest Protection in Ghana (p. 203). Gland, Cambridge: IUCN.

Heusèrr, M. J. J. (1998). Putting Diversity Indices into Practice. In Proceedings of the Conference on Assessment of Biodiversity for Improved Forest Planning (p. 173). 7-11 October 1996, Monte Verità, Switzerland. https://doi.org/10.1007/978-94-015-9006-8_16

Intergovernmental Panel on Climate Change (IPCC) (2006). IPCC Guidelines for National Greenhouse Gas Inventories.

Jamnadass, R. H., Dawson, I. K., Franzel, S., Leakey, R. R. B., Mithöfer, D., Akinnifesi, F. K., \& Tchoundjeu, Z. (2011). Improving Livelihoods and Nutrition in Sub-Saharan Africa through the Promotion of Indigenous and Exotic Fruit Production in Smallholders' Agroforestry Systems: A Review. International Forestry Review, 13, 338-354. https://doi.org/10.1505/146554811798293836

Kauffman, J. B., \& Donato, D. C. (2012). Protocols for the Measurement, Monitoring and Reporting of Structure, Biomass, and Carbon Stocks in Mangrove Forests. Bogor: CIFOR.

Kent, M., \& Coker, P. (1996). Vegetation Description and Analysis (pp. 1415, 96-105). Hoboken, NJ: John Wiley Sons.

Krebs, C. J. (2001). Ecology; the Experimental Analysis of Distribution and Abundance (5th ed.). Vancouver: The University of British Columbia.

Kuyah, S., Johannes, D., Muthuri, C., Ramni, J., Mwangi, P., Coe, R., \& Neufeldt, H. (2012). Allometric Equations for Estimating Biomass in Agricultural Landscapes: I. Aboveground Biomass. Agriculture, Ecosystems \& Environment, 158, 216-224. https://doi.org/10.1016/j.agee.2012.05.011

Lamprecht, H. (1989). Silvicultural in the Tropics Forest Ecosystems and Their Tree Species, Possibilities and Methods for Their Long-Term Utilization (p. 343). Eschborn: Deutsche Gesellschaft fürTechnische Zusammenarbeit (GTZ).

Lawson, G. W. (1986). Plant Life in West Africa. Accra: Ghana University Press.

Montagnini, F., Gonzalez, E., Rheingans, R., \& Porras, C. (1995). Mixed and Pure Forest Plantations in the Humid Neotropics: A Comparison of Early Growth, Pest Damage and Establishment Costs. The Commonwealth Review, 74, 306-314.

Montagnini, F., \& Nair, P. K. R. (2004). Carbon Sequestration: An Underexploited Environmental Benefit of Agroforestry Systems. Agroforestry Systems, 61, 281-295. https://doi.org/10.1007/978-94-017-2424-1_20

Ngueguim, J. R., Zapfack, L., Youmbi, E., Riera, B., Onana, J., Foahom, B., \& Makombu, J. G. (2010). Diversité floristiquesous canopéeen plantation forestièrede Mangombe-Edea (Cameroun). Biotechnologie, Agronomie, Sociétéet Environment, 14, 167.

Nketia, K. S. (2002). Pruning of Trees Shrubs and Conifers (p. 54). London: Faber and Faber.

Nkyi, A. (2007). Introduction to Tropical Forest Measurements (p. 64). Kumasi: Asare 
Patrick Printing Press.

Oliver, C. D., \& Larson, B. C. (1990). Forest Stand Dynamics (p. 467). New York: McGraw-Hill.

Oliver, C. D., \& Larson, B. C. (1996). Forest Stand Dynamics (p. 518). New York: Wiley.

Opoku, M. S. (2012). Growth and Productivity of Khaya grandifoliola in the Dry Semi Deciduous Forest of Ghana: A Comparison in Pure Stands and in Mixed Stands. Thesis, Department of Materials Engineering, Kwame Nkrumah University of Science and Technology.

Opuni-Frimpong, E. (2008). Khaya grandifolia C.D.C. In D. Louppe, A. A. Oteng-Amoako, \& M. Brink (Eds.), Plant Resources of Tropical Africa 1(1): Timbers 1 (pp. 329-333). Leiden: Backhuys Publishers.

Orwa, C., Mutua, A., Kindt, R., Jamnadass, R., \& Anthony, S. (2009). Agroforestree Database: A Tree Reference and Selection Guide Version 4.0.

Otsamo, R. (2000). Early Development of Three Planted Indigenous Tree Species and Natural Understory Vegetation in Artificial Gaps in an Acacia mangium Stand on an Imperata cylindrica Grassland Site in South Kalimantan, Indonesia. New Forests, 19, 51-68. https://doi.org/10.1023/A:1006685103365

Parthasarathy, N. (2001). Changes in Forest Composition and Structure in Three Sites of Tropical Evergreen Forest around Sengaltheri, Western Ghats. Current Science, 80, 389-393.

Parrotta, J. A., \& Knowles, O. H. (1999). Restoration of Tropical Moist Forests on Bauxite-Mined Lands in the Brazilian Amazon. Restoration Ecology, 7, 103-116. https://doi.org/10.1046/j.1526-100X.1999.72001.x

Petit, B., \& Montagnini, F. (2006). Growth in Pure and Mixed Plantations of Tree Species Used in Reforesting Rural Areas of the Humid Region of Costa Rica, Central America. Forest Ecology and Management, 233, 338-343. https://doi.org/10.1016/j.foreco.2006.05.030

Piotto, D. (2008). A Meta-Analysis Comparing Tree Growth in Monocultures and Mixed Plantation. Forests Ecology and Management, 225, 781-786. https://doi.org/10.1016/j.foreco.2007.09.065

Potvin, C., \& Dutilleul, P. (2009). Neighborhood Effects and Size-Asymmetric Competition in a Plantation Varying in Diversity. Ecology, 90, 321-327.

https://doi.org/10.1890/08-0353.1

Redondo-Brenes, A. (2007). Growth, Carbon Sequestration, and Management of Native Tree Plantations in Humid Regions of Costa Rica. New Forest, 34, 253-268. https://doi.org/10.1007/s11056-007-9052-9

Redondo-Brenes, A., \& Montagnini, F. (2006). Growth, Productivity, Biomass and Carbon Sequestration of Pure and Mixed Native Tree Plantations in the Atlantic Lowlands of Costa Rica. Forest Ecology Management, 232, 168-178.

https://doi.org/10.1016/j.foreco.2006.05.067

Ryan, M. G. (1991). A Simple Method for Estimating Gross Carbon Budgets for Vegetation in Forest Ecosystem. Tree Physiology, 9, 255-266.

https://doi.org/10.1093/treephys/9.1-2.255

Schroeder, P. (1992). Carbon Storage Potential of Short Rotation Tropical Tree Plantations. Forest Ecology Management, 50, 31-41. https://doi.org/10.1016/0378-1127(92)90312-W

Senbeta, F., Schmitt, C., Denich, M., Demissew, S., Vlek, P. L. G., Preisinger, H., Woldemariam, T., \& Teketay, D. (2005). The Diversity and Distribution of Lianas in the 
Afromontane Rain Forests of Ethiopia. Diversity and Distributions, 11, 443-452. https://doi.org/10.1111/j.1366-9516.2005.00180.x

Ssegawa, P., \& Nkuutu, D. N. (2006). Diversity of Vascular Plants on Ssese Islands in Lake Victoria, Central Uganda. African Journal of Ecology, 44, 22-29. https://doi.org/10.1111/j.1365-2028.2006.00609.x

Shepherd, D., \& Montagnini, F. (2001). Carbon Sequestration Potential in Mixed and Pure Tree Plantations in the Humid Tropics. Journal of Tropical Forest Science, 13, 450-459.

Stanley, W. G., \& Montagnini, F. (1999). Biomass and Nutrient Accumulation in Pure and Mixed Plantations of Indigenous Tree Species Grown on Poor Soils in the Humid Tropics of Costa Rica. Forest Ecology and Management, 113, 359-372. https://doi.org/10.1016/S0378-1127(98)00417-4

Tang, C. Q., Hou, X., Gao, K., Xia, T., Duan, C., \& Fu, D. (2007). Man-Made versus Natural Forests in Mid-Yunnan, Southwestern China: Plant Diversity and Initial Data on Water and Soil Conservation. Mountain Research and Development, 27, 242-249. https://doi.org/10.1659/mrd.0732

Tilman, D. (1988). Plant Strategies and the Dynamics and Structure of Plant Communities. Princeton, NJ: Princeton University Press.

Ugalde, L. A. (2000). El sistema MIRA. In Componente de Silvicultura (p. 82). Turrialba: Manual del Usuario (CATIE).

Vanclay, J. K. (2006). Experiment Designs to Evaluate Inter and Intra-Specific Interactions in Mixed Planting of Forest Trees. Forest Ecology and Management, 233, 366-374. https://doi.org/10.1016/j.foreco.2006.05.034

World Bank (1988). Staff Appraisal Report: Ghana Forest Resource Management Project. Unpublished Report No. 7295-GH, Washington DC: Western African Department, Agricultural Operations Division, World Bank.

World Bank (2016). Forest Generate Jobs and Income. Washington DC: The World Bank IBRD-IDA. 